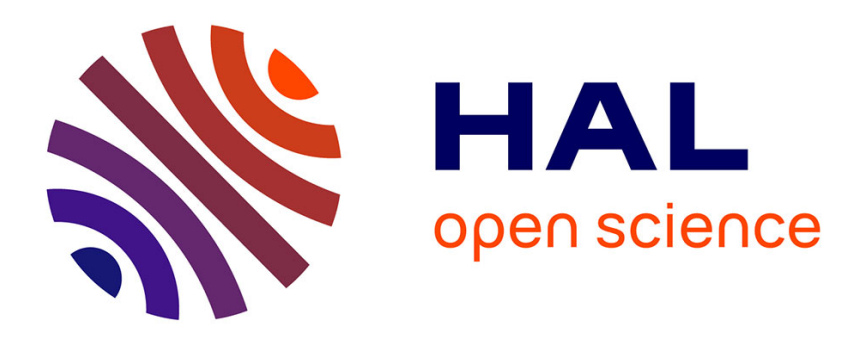

\title{
Ploidy of embryogenic Medicago sativa subsp. falcata germplasms
}

François Blondon, Spencer Brown

\section{To cite this version:}

François Blondon, Spencer Brown. Ploidy of embryogenic Medicago sativa subsp. falcata germplasms. Agronomie, 1999, 19 (1), pp.69-72. hal-00885914

\section{HAL Id: hal-00885914 https://hal.science/hal-00885914}

Submitted on 1 Jan 1999

HAL is a multi-disciplinary open access archive for the deposit and dissemination of scientific research documents, whether they are published or not. The documents may come from teaching and research institutions in France or abroad, or from public or private research centers.
L'archive ouverte pluridisciplinaire HAL, est destinée au dépôt et à la diffusion de documents scientifiques de niveau recherche, publiés ou non, émanant des établissements d'enseignement et de recherche français ou étrangers, des laboratoires publics ou privés. 
(C) Inra/Elsevier, Paris

\title{
Original article
}

\section{Ploidy of embryogenic Medicago sativa subsp. falcata germplasms}

\author{
François Blondon*, Spencer Brown \\ Institut des Sciences Végétales, UPR040, Centre national de la recherche scientifique, avenue de la Terrasse, \\ 91198 Gif-sur-Yvette cedex, France
}

(Received 15 June 1998; revised 23 June 1998; accepted 2 December 1998)

\begin{abstract}
The germplasms Medicago sativa L. subsp. falcata WY-RF1 (Reg. no. GP-263, PI 564263) and WY-RF2 (Reg. no. GP-264, PI 564262), maintained at the Wyoming Agricultural Experimental Station, were reported to have improved regeneration capacity, to be embryogenic and are registered as diploid. We show that, in fact, germplasm WYRF1 is diploid but WY-RF2 is tetraploid. The latter is more vigorous, but the two have close flowering times. The mean $2 \mathrm{C}$ nuclear DNA values from flow cytometry using ethidium bromide, verified upon many seeds including those from descendants, were: $1.88 \mathrm{pg}$ for RF1 ( $1 \mathrm{C}=907$ million base pairs) and $3.41 \mathrm{pg}$ for RF2 ( $1 \mathrm{C}=1645$ million base pairs). Chromosome numbers in root meristem metaphases were, respectively, $2 \mathrm{n}=16$ and 32 . This distinction is capital for biotechnological and genetic studies. (ㅇ Inra/Elsevier, Paris.)
\end{abstract}

genome-size / ploidy / flow cytometry / embryogenesis / Medicago sativa L. subsp. falcata

Résumé - Ploïdie de lignées embryogènes de Medicago sativa subsp. falcata. À la station expérimentale d'agriculture du Wyoming (États-Unis), deux lignées de Medicago sativa L. subsp. falcata WY-RF1 (Reg. no. GP-263, PI 564263) et WY-RF2 (Reg. no. GP-264, PI 564262) ont été sélectionnées pour leurs capacités de régénération et d'embryogenèse in vitro. Ces deux lignées sont définies comme étant diplö̈des. Nous montrons, entre autres, que si la lignée WY-RF1 est bien diploïde par contre la lignée WY-RF2 est tétraploïde. Le temps nécessaire pour obtenir la floraison est proche pour les deux lignées mais la tétraplö̈de est plus vigoureuse. La valeur moyenne de la teneur en ADN, déterminée par cytométrie en flux avec le bromure d'éthidium, est de 1,88 pg pour WY-RFI ( $1 \mathrm{C}=907$ millions de paires de bases) et 3,41 pg pour WY-RF2 $(1 \mathrm{C}=1645$ millions de paires de bases $)$. Le nombre de chromosomes, dans les pointes racinaires, est de 16 pour WY-RF1 et de 32 pour WY-RF2. Ces lignées sont utilisées dans des expériences génétiques et de transformations, ce qui rend capital la connaissance de leur niveau de plö̈die et de leur teneur en ADN. (@ Inra/Elsevier, Paris.)

taille du génome / ploïdie / cytométrie en flux / embryogenèse / Medicago sativa L. subsp. falcata

Communicated by Hervé Thiellement (Genève, Switzerland)

* Correspondence and reprints

E-mail: francois.blondon@isv.cnrs-gif.fr 


\section{INTRODUCTION}

Medicago sativa L. subsp. sativa (alfalfa) can be readily regenerated from tissue, apparently owing to its tetraploidy [2], and somatic embryogenesis is obtained [8]. The diploid Medicago species unfortunately are much more recalcitrant to regeneration, although major progress has been made $[6,10,11$, 14-16]. The agronomic tetraploid cultivars of subsp. sativa are composite, often including part of the genome of Medicago sativa subsp. falcata. Germplasms of these contributing subspecies with high regeneration capacity are useful, notably if they are diploid. They may be essentially allogamous, but with a certain frequency of autogamy. Here we report on two germplasms of Medicago sativa subsp. falcata with high regeneration capacities [10], one of which we show to be tetraploid in contrast to its registration as a diploid.

\section{MATERIALS AND METHODS}

Seeds of Medicago sativa L. subsp. falcata WY-RF1 (Reg. no. GP-263, PI 564263) and WY-RF2 (Reg. no. GP-264, PI 564262), both registered as diploid, were kindly provided by R.W. Groose at the Wyoming Agricultural Experimental Station, as duplicate dispatches to A. Kondorosi and to E. Kondorosi. WY-RF1 and WY-RF2 were developed by Groose and $\mathrm{Li}$ by three cycles of recurrent phenotypic selections from accessions PI 251830 (Austria) and PI 260993 (Russia), so improving from initial somatic embryogenesis frequencies of 46 and $39 \%$ to 100 and $93 \%$, respectively. Their culture in vitro was only used as an assay and was never the source of germplasm.

Our plants were sown in a glasshouse with $16 \mathrm{~h}$ natural light complemented by incandescent and fluorescent sources for $15 \mathrm{~W} \cdot \mathrm{m}^{-2}$ and $22{ }^{\circ} \mathrm{C}$ constant temperature, $70 \%$ relative humidity, using vermiculite and nutrient solution [3], conducive to good pollen viability [4]. Field plants were also grown at Gif-sur-Yvette.

\subsection{Light microscopy}

Root tips of $2 \mathrm{~cm}$ were taken from germinated seeds, transferred to saturated $\alpha$-bromonaphthalene [1] for 60 min at room temperature to accumulate metaphases. After rinsing with distilled water, root-tips were fixed in absolute ethanol/acetic acid, $3: 1(\mathrm{v} / \mathrm{v})$ for $24-48 \mathrm{~h}$, then stored at $-20^{\circ} \mathrm{C}$. Later, fixed roots were abundantly rinsed with water and the digestion of the meristem was carried out using an enzyme mixture $(0.25 \%$ pectolyase Y23, $3 \%$ cellulase Onozuka R-10, $0.4 \mathrm{M}$ sorbitol, $\mathrm{pH}$ 5.5 ) at $37^{\circ} \mathrm{C}$. After $60 \mathrm{~min}$ maceration, the root-tips were transferred to cold $45 \%$ acetic acid for $15 \mathrm{~min}$. Single root-tips were taken with a $20 \mu \mathrm{L}$ pipette onto slides before gentle squashing in one drop of $45 \%$ acetic acid. A Diaplan phase contrast optic was used with PanF 50ASA Ilford film.

\subsection{Flow cytometry}

Nuclei were isolated mechanically, similar to [5]. One leaflet was chopped with a razor-blade in $600 \mu \mathrm{L}$ cold buffer [9] supplemented with $5 \mathrm{mM}$ sodium metabisulfite with about $1 \mathrm{~cm}^{2}$ piece of leaf of the internal standard, Petunia hybrida PxPC6 $(2 \mathrm{n}=2 \mathrm{x}=14 ; 2 \mathrm{C}=2.85$ pg DNA) [12]. This was filtered through $48 \mu \mathrm{m}$ nylon, treated with $5 \mathrm{U} / \mathrm{mL}$ final Ribonuclease A (Boehringer no. 109169 DNase-free) and stained with $50 \mu \mathrm{g} / \mathrm{mL}$ ethidium bromide for $15 \mathrm{~min}$, prior to flow cytometry (EPICS V, Coultronics France, Margency) with the laser at $514 \mathrm{~nm}$ and taking the emission above $590 \mathrm{~nm}$. The ratio of fluorescence intensity of the $2 \mathrm{C}$ peaks was used to calculated the $2 \mathrm{C}$ value of Medicago, taking a linear relationship. Data were treated by analysis of variance followed by the F-test.

\section{RESULTS}

For glasshouse plants with 2-3 trifoliate leaves, the $2 \mathrm{C}$ nuclear DNA means $\pm \mathrm{SE}$ from flow cytometry with ethidium bromide were: $1.88 \pm 0.022 \mathrm{pg}$ (degrees of freedom, $\mathrm{df}=11$ ) for RF1 and $3.41 \pm$ $0.023 \mathrm{pg}(\mathrm{df}=8)$ for RF2. The F-test indicated that the variance was the same in the two populations, RF1 and RF2. These mean values have a confidence interval of about $2 \%$. However, with field samples, exceptions occurred during the 3 year programme even on clonal material when our estimates became dependent upon the day of analysis: at its extreme, $7 \%$ systematic variation was observed 
under particular seasonal conditions and growth stages.

Self-pollination seeds were harvested from these glasshouse plants and resown. In this second generation, sibling plants from RFl gave $2 \mathrm{C}$ values (each the mean of six measurements) of $1.86,1.88,1.90$ and $1.92 \mathrm{pg}$. Likewise, for the second generation of RF2, one lot of siblings gave $2 \mathrm{C}$ values of 3.53 , 3.58 and $3.66 \mathrm{pg}$; a second lot of siblings gave 3.42 , 3.43 and 3.46 ; a third lot $3.41,3.43$ and $3.44 \mathrm{pg}$; a fourth $\operatorname{lot} 3.39,3.41$ and $3.46 \mathrm{pg}$. In more than 100 independent measurements of plants grown under glasshouse or field conditions, no exception has been found to the clustering of RF1 and RF2.

Chromosome numbers on six individuals of each germplasm were consistent: $2 \mathrm{n}=16$ for $\mathrm{RF} 1$ and $2 \mathrm{n}$ = 32 for RF2 (figure 1).

Under glasshouse conditions, RF1 and RF2 have their flowering dates close: flower emergence began at 46-52 days and 50-56 days, respectively. The generation time was 4 months. In the field, RF1 began spring growth 1 week later but the genotypes had similar flowering dates (mid- till late-June at Gif-sur-Yvette according to the year). RF2 was clearly more vigorous: in the field, the average surface of an adult leaf was about double that of RF1; in the glasshouse, it was $20 \%$ larger.

\section{DISCUSSION}

Here the 2C DNA values, the chromosome counts, and the phenotype show that $M$. sativa subsp. falcata RF1 is diploid ( $2 \mathrm{n}=16$ with $1.88 \mathrm{pg}$ DNA) and RF2 is tetraploid ( $2 n=32$ with $3.41 \mathrm{pg}$ DNA). These genotypes originate from Austria (RF1) and Russia (RF2).

In an earlier study [5] the closely related diploid Russian ecotype of $M$. sativa subsp. quasifalcata had 2C DNA of $1.72 \mathrm{pg}$; RF2 has double this value. Other values concerning $M$. sativa subsp. falcata, deduced by Blondon et al. [5] from Essad [7], were 1.49 and $1.97 \mathrm{pg}$ for diploid ecotypes and $2.82 \mathrm{pg}$ for a tetraploid. There is clearly intraspecific variation of both genome size and ploidy level. As the
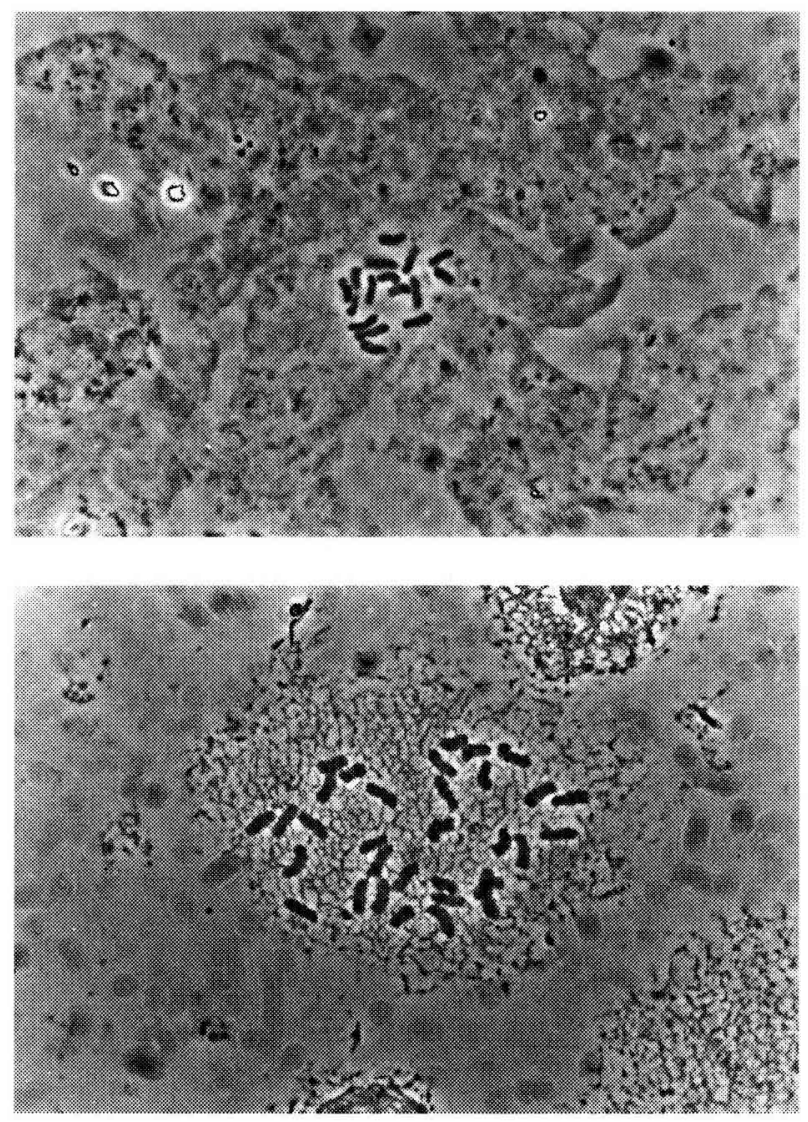

Figure 1. Metaphase spreads of $\alpha$-bromonaphthalene treated root tissues from Medicago sativa subsp. falcata. (upper) WY RF1; (lower) WY-RF2. Phase contrast; magnification $\times 1800$.

present study concerns germplasm derived from different sources, the fact that the tetraploid genome is not exactly twice that of the diploid is not surprising. Over 100 plants have been analysed, covering two generations, without finding any exception to these systematic diploid and tetraploid groupings. This is not surprising: we recall that these germplasms are not the product of in vitro manipulation, so somaclonal variation should not be present.

The $1 \mathrm{C}$ value for RF1 was $0.94 \mathrm{pg}$, equivalent to 907 million base pairs. The mean genome size of RF2, 1645 million base pairs, was $181 \%$ that of RF1. 
Given the intraspecific variation of the Medicago genomes which exhibit much plasticity, given their frequent use for genetic manipulation and their agronomic significance, we propose that flow cytometry should be more routinely applied as a quality control [12]. One demonstration of this practice comes from research into somatic embryogenesis in rose cultures [13]. This is all the more necessary when culture conditions risk to introduce somaclonal variation, such as during in vitro manipulations.

Acknowledgements: The flow cytometry was efficiently conducted by Danièle De Nay, Marie-Thérèse Crosnier and Jean-Marc Bureau, who are warmly thanked. This equipment is partly supported by an INCO-COPERNICUS study, grant \#PL966067. The efficient contribution of Mona Abirached-Darmency and Bernadette Anton-Lopez (INRA, Dijon) for cytogenetics (figure 1) has been appreciated. We thank R.W. Groose for the seeds, and trust that this report enhances the value of his collection.

\section{REFERENCES}

[1] Agarwal K., Gupta P.K., Cytological Studies in the Genus Medicago Linn., Cytologia 48 (1983) 781-793.

[2] Bingham E.T., Hurley L.V., Kaatz D.M., Saunders J.W., Breeding alfalfa which regenerates from callus tissue in culture, Crop Sci. 15 (1975) 719-721.

[3] Blondon F., Chesnaux M.T., Guy P., Action de deux photoperiodes et de thermoperiodes sur le comportement de deux types extrêmes de Luzernes françaises, Medicago sativa L, C. R. Acad. Sci. Ser. III Sci. Vie 264 (1967) 596-598.

[4] Blondon F., Ghesquiere M., Guy P., Variation de la fertilité pollinique en fonction de la température chez des luzernes de différentes origines (Medicago sativa $\mathrm{L}$. et $M$. media Pers.), Agronomie 1 (1981) 383-388.

[5] Blondon F., Marie D., Brown S.C., Kondorosi A., Genome size and base composition in Medicago sativa and $M$. truncatula species, Genome 37 (1994) 264-270.

[6] Chabaud M., Larsonneau C., Marmouget C., Huguet T., Transformation of barrel medic (Medicago truncatula Gaetern.) by Agrobacterium tumefaciens and regeneration via somatic embryogenesis of transgenic plants with the MtENOD12 nodulin promotor fused to the gus reporter gene, Plant Cell Rep. 15 (1996) 305-310.

[7] Essad S., Mise en évidence de variations saltatoires de l'ADN nucléaire dans et entre les espèces du genre Medicago L., Genome 30 (1988) 825-834.

[8] Finstad K., Brown D.C.W., Joy K., Characterization of competence during induction of somatic embryogenesis in alfalfa tissue culture, Plant Cell Tiss. Org. Cult. 34 (1993) 125-132.

[9] Galbraith D.W., Harkins K.R., Maddox J.M., Ayres N.M., Sharma D.P., Firoozabady E., Rapid flow cytometric analysis of the cell cycle in intact plant tissues, Science 220 (1983) 1049-1051.

[10] Groose R.W., Li Y.G., Registration of diploid alfalfa (Medicago sativa ssp. falcata) germplasms for biotechnology research and development, Crop Sci. 33 (1993) 1116.

[11] Hoffmann B., Trinh T.H., Leung J., Kondorosi A., Kondorosi E., A new Medicago truncatula line with superior in vitro regeneration, transformation and symbiotic properties isolated through cell culture selection, Mol. Plant-Microbe Interact. 10 (1997) 307-315.

[12] Marie D., Brown S.C., A cytometric exercise in plant DNA histograms, with $2 \mathrm{C}$ values for 70 species, Biol. Cell 78 (1993) 41-51.

[13] Moyne A.L., Souq F., Yean L.H., Brown S.C., Boulay M., Sangwan-Norreel B.S., Relationship between cell ploidy and regeneration capacity of long term Rosa hybrida cultures, Plant Sci. 93 (1993) 159-168.

[14] Nolan K.E., Rose R.J., Gorst J.R., Regeneration of Medicago truncatula from tissue culture: Increased somatic embryogenesis using explants from regenerated plants, Plant Cell Rep. 8 (1989) 278-281.

[15] Ray I.M., Bingham E.T., Breeding diploid alfalfa for regeneration from tissue culture, Crop Sci. 29 (1989) 1545-1548.

[16] Trinh T.H., Ratet P., Kondorosi E., Durand P., Kamaté K., Bauer P., Kondorosi A., Rapid and efficient transformation of diploid Medicago truncatula and Medicago sativa subsp. falcata lines improved in somatic embryogenesis, Plant Cell Rep. 17 (1998) 345-355. 